\title{
Modelling a production process using a Sankey diagram and Computerized Relative Allocation of Facilities Technique (CRAFT)
}

https://doi.org/10.1515/eng-2019-0043

Received Mar 28, 2019; accepted May 15, 2019

\begin{abstract}
This paper constitutes a partial output of carried out research and is focused on modelling the production process of car seat manufacturing. Given that manufacturing companies are currently struggling with a shortage of qualified workforce, it is the job of every business to keep their current employees. Companies make efforts to operate the most efficient production processes at very low cost and with labour saving. In order to produce at low cost, the work environment must be designed efficiently. There are many ways to do this. In this paper focused on optimizing production processes, Computerized Relative Allocation of Facilities Technique (CRAFT) and a Sankey diagram will be used.
\end{abstract}

Keywords: Production Logistics, Operational Research, Optimalization of production processes

\section{Introduction}

Logistics as a scientific discipline began to manifest itself at the beginning of this century. In the 1960s, Peter Drucker came up with the idea that logistics helped increase business efficiency. Since then, more emphasis has been placed on logistics than in the past. At present, logistics is key to helping to improve market positions and gain competitive advantage [1]. Most companies strive to find a competitive advantage in the globalization environment to help them get closer to customers and maintain a good market position. For this reason, logistics has become an important part of modern management of compa-

\footnotetext{
*Corresponding Author: Hlatká Martina: Vysoká škola technická a ekonomická v Českých Budějovicích, Okružní 17, Department of Transport and Logistics; Email: hlatka@mail.vstecb.cz Kampf Rudolf: Vysoká škola technická a ekonomická v Českých Budějovicích, Okružní 17, Department of Transport and Logistics; Email: kampf@mail.vstecb.cz
}

nies; it is logistics departments that organize the flow of material in the production process, coordinate transport and transportation processes, provide customer service and help ensure the smooth operation of the sophisticated system of the company with the lowest operating costs of departments [2-4]. Logistics uses innumerable methods of mathematical modelling and other exact methods for modelling the workplace in order to reduce production times. This reduction has the effect of decreasing both the company's costs and the efforts of individual employees [5-7]. This field can support Samuelson's variational principle. It means that maniplation's costs should decrease to minimalize value [8].

\section{The production process of car seats}

This paper is focused on technological, handling and control operations at a selected workplace, where passenger car seats are produced. The production process takes place through a high material flow that is associated with the movement of raw materials, components and semifinished products [9]. The material flow is formed on the basis of the technological procedure of seat production. High emphasis is placed on quality production, as the car seat represents one of the elements of passive safety. Front and rear seats are assembled completely in the company. They consist of a steel support frame that is reinforced by a wire reinforcement and a seat frame, which is located on the front guide rail. Electronic and pneumatic systems are placed inside the prepared frame according to the order. The seats have thirteen possibilities of electronic control. Then they are filled with a foam pad. Everything is hidden in the design cover. The spatial arrangement of the company plays a big part in the efficiency of production [10]. In cooperation with the manufacturing company, it will be verified that the workplace is arranged optimally and cannot be better organized in terms of cost and time savings.

๑ Open Access. (c) 2019 K. Rudolf and H. Martina, published by De Gruyter. 
All production processes are closely linked to each other and follow the customer's production processes. For this reason, the emphasis is placed on speed and reliability of delivery [11]. Product assembly takes place in several production departments, as shown in Figure 1.

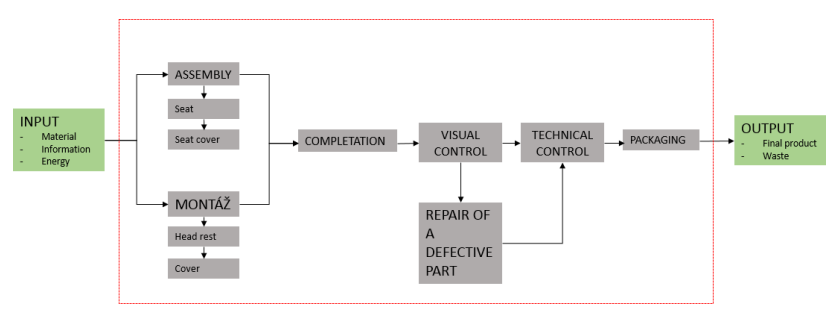

Source: The authors

Figure 1: The production process

As mentioned above, material flow management is based on the technological procedure of the manufacturing process as defined by an internal directive. Materials inventory and the supply chain play an important role in the production. The company is based on just-in-time production [12-16]. The material is transported to the assembly hall by an autonomous device in the order of seat assembly and distributed to the designated workplace of the production line. The individual flows of material are shown in Figure 2.

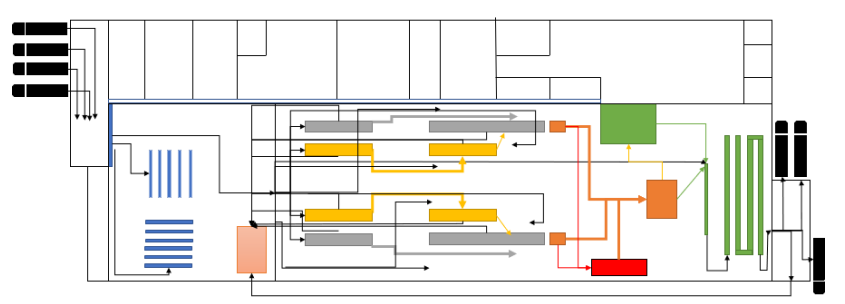

Source: The authors

Figure 2: The flows of material in the production of seats

A mathematical modelling method CRAFT (Computerized Relative Allocation of Facilities Technique) and a Sankey diagram will be used to analyse the workplace layout [17].

Sankey diagrams serve to illustrate the flow of material between workplaces. The use of this method is possible for both smaller and automated or semi-automated production processes. The basis for its use is the ground plan of the building and the construction of a checkerboard [18, 19]. The results are represented by a diagram where the flow rate is indicated by the width of the arrow and the distance between the workplaces by the length of the ar- row. For better clarity, different colours are used to represent the individual types of material transported [20, 21].

Computerized Relative Allocation of Facilities Technique (CRAFT) method is suitable for use in assembly line plants or mass production plants where multiple component products are assembled. This method is used to determine the most suitable position of two elements in the overall layout and serves to organize the space of a workplace. CRAFT can be applied if it is guaranteed that the workplace determined the order of the product in terms of the technological procedure [22, 23]. Before this method is implemented, any workplace layout (suitable for using already existing processes) is selected and the changing of workplaces is carried out in a few steps until the handling costs are the lowest. It is taken into account during the calculations that the workplaces may have a fixed position or may be adjacent to other workplaces [24, 25]. CRAFT is a mathematical method that will be applied to determine the optimal distribution of elements in the production process [26]. The solution will be done by means of a mathematical model using the following elements [27]:

$\mathrm{n}$ - number of activities within the workplace, department, workshop

vij - number of load units between the activities

uij - handling costs (distances between the activities)

lij - distance between the activities

The final solution that will result in cost and volume optimization will be used to create the model. The formula for calculating the cost of movement will be given by the relationship:

$$
c_{i j}=u_{i j} \times v_{i j}
$$

Changing the layout of departments will change the distance between the workplaces, and the cost of the layout will be expressed by the relationship:

$$
N=\sum_{i=1}^{n} \sum_{j=1}^{n} c_{i j} \times l_{i j}
$$

\section{Research}

Firstly, a matrix table is created consisting of details about the material transported during the production program within one day in pieces. These values are obtained from the economic department. The individual movements from the warehouse to the production processes are all presented in Table 1 without their division to the production lines.

To build the Sankey diagram, e-sankey demo version program was used. The input data for the compilation 


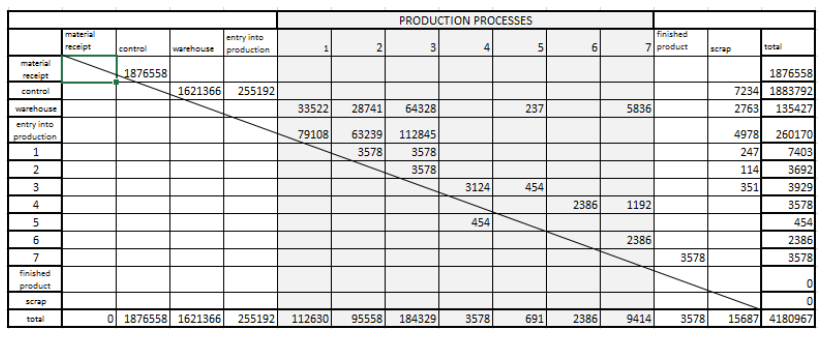

Source: The authors

Table 1: The flows of material in pieces

of the diagram are based on the table above. In the diagram, the blue colour represents the material flows, the red colour represents the flows of semi-finished and finished products. The products designed for repairing defective components are green and run from process three to process five. The reverse flows of material and scrap are shown in orange [28]. The fully-constructed Sankey diagram is shown in Figure 3.

The Sankey diagram revealed frequent crossings of routes, which indicates an inappropriately arranged workplace. The flows of material intersect the reverse flows of mixed and recycled waste. The CRAFT method will be used to design a new workplace layout. The costs are determined using standard costs and price deviations. Standard costs used in cost accounting are determined before the start of production and represent the norms for unit costs. The costs between the individual processes are shown in Table 2 and are expressed in Czech crowns. The data are set to three-shift operation over one working day and two assembly lines. The purpose of applying the CRAFT method is to find a workplace layout with minimum handling costs [28, 29]. At the same time, the implementation of the new layout design must not be costly for the company. The handling costs of material and semi-finished products do not have a specified unit handling cost because of the use of several material transfer methods during the production process. In order to apply CRAFT, it was first necessary to determine the flows of material between the workplaces for the original layout. In addition, it was necessary to specify the cost of material handling per day for the original layout. The costs of the flows of material before optimization in CZK are shown in Table 2.

Distances between the individual objects are shown in Table 3. The distances are in meters. The largest distance is between the warehouse and process 7 , where the packing line is located. Here the products must be properly packed prior to their loading into a vehicle and it is necessary to move the packaging from the warehouse. Also, a long way must be overcome by the employees in order to transport

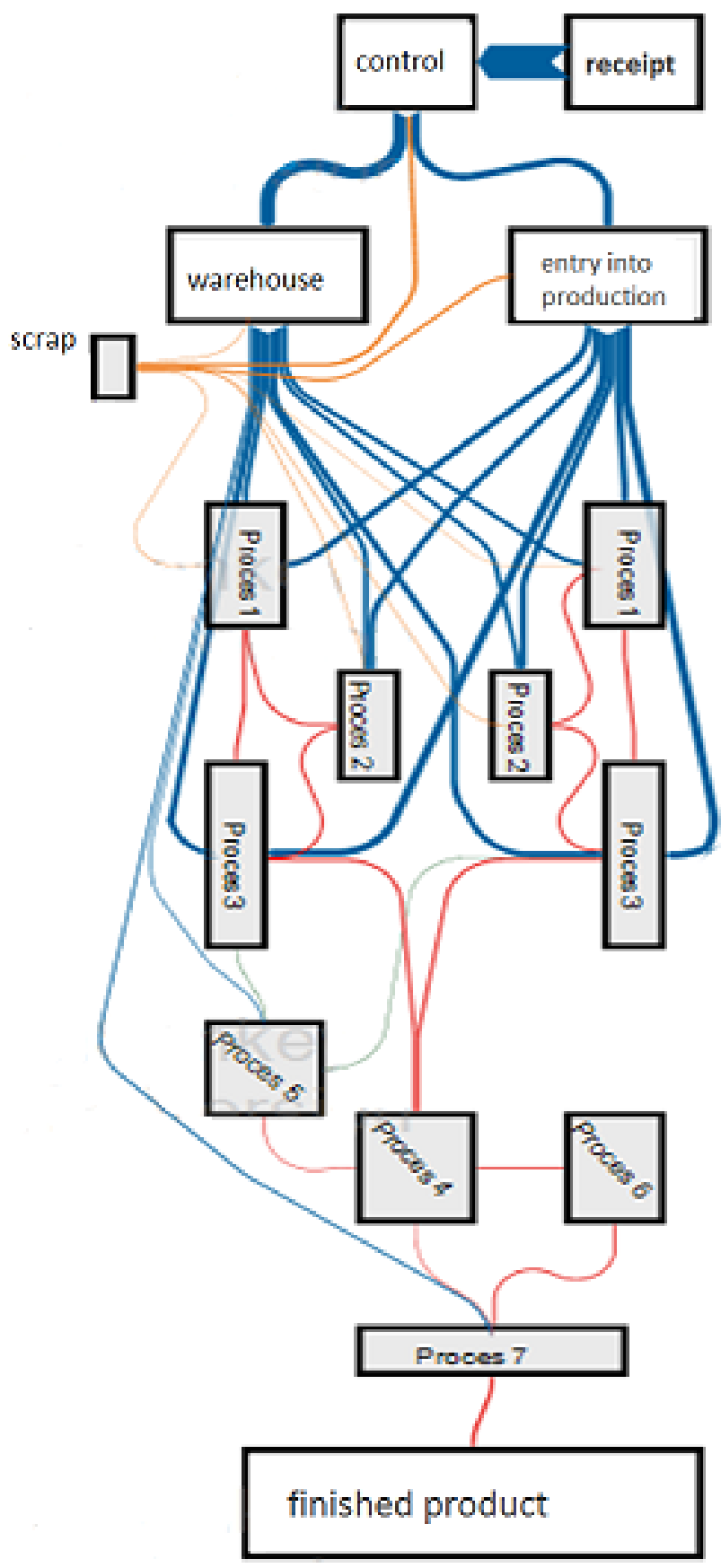

Source: The authors

Figure 3: Sankey diagram

material when delivering components to repair a defective part, which is happening in process 5 . However, in this case, the routes are not regular and the company is not able to create a warehouse near the repair line. 


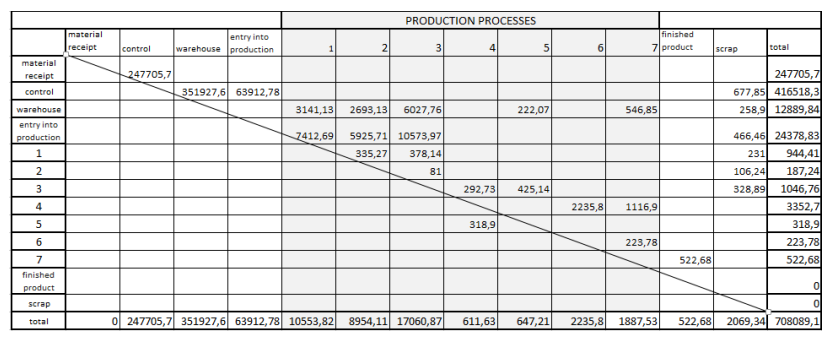

Source: The authors

Table 2: Material handling costs in CZK

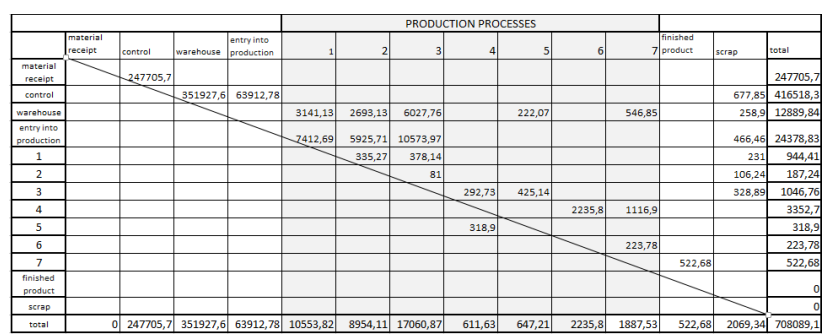

Source: The authors

Table 3: Distances between the objects in meters

\section{Research findings}

The production processes were evaluated during the analysis. In order to reduce handling costs, investment in a belt conveyor was proposed, which would limit the steps of the operators in process 2 and process 3 when they need to go get semi-finished products. There is currently a two-meter gap that the operators have to overcome. The belt conveyor would become a part of the assembly line's technological equipment and would convey the prepared seats continuously to the location where the seat assembly machine is located. Its design is shown in Figure 4.

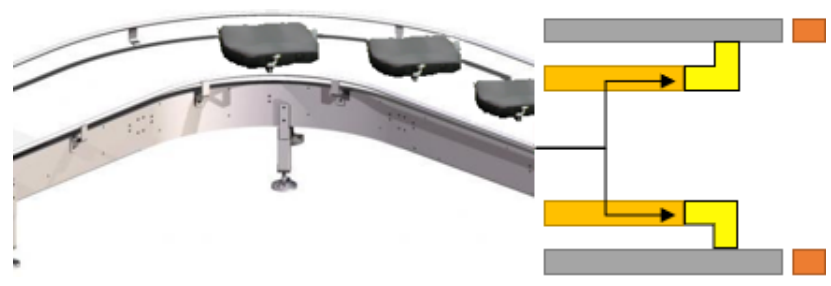

Source: The authors

Figure 4: Design of a conveyor belt

The removal of the material would take place without unnecessary steps and the operator would only assemble the seats. Another proposal for material flow optimization is to move the workplace where defective parts of the product are repaired to the middle of the production hall so that both production lines have the same distance from discarded defective products. This would result in reducing the overall costs of the process. At the same time, the distance between this workplace and the warehouse will be reduced. Moving process 5 closer to the production lines will decrease the average distance between the processes by $19.11 \mathrm{~m}$. The resulting distance would be $25.74 \mathrm{~m}$. In this case, the costs would decrease by CZK 181.16 per day. This amount may appear to be negligible for the company, but in case of annual recalculation, the total cost would be CZK 76128 if process 5 was located closer to the production lines. If this change is made, it is necessary to recalculate the costs that are incurred during the handling of the products from the warehouse. Here, the resulting average distance will be reduced to 74.9 meters and the costs will be reduced by CZK 50.31; the total annual costs for moving material from the warehouse to process 5 will be CZK 52 965.12. If we add to these amounts the cost of moving the workplace (CZK 3 250), the total costs are CZK 132343.12. Before the change, the total costs were CZK 201 311.76. It is evident that even in the case of investing in the relocation of the manufacturing site for process 5 , it would make a significant benefit for the company in the first year of its implementation.

In order to eliminate unnecessary handling costs during the transfer of products from the packaging line to the place where the finished products are put aside ready for loading, it would be appropriate for the company to join these two phases of the production process. Since a complete product is already produced and packaged, the handling is very costly. If these two phases were linked, the company would save CZK 522.68 per day. The new arrangement of finished products and packing lines could contribute to speeding up loading where loading would take place simultaneously into two cars.

Table 4 shows the cost change for the new layout of production including the establishment of a conveyor belt. The total costs after optimization are CZK 706 988.4. The workplace was adjusted based on these changes. Figure 5 below shows the resulting layout of the workplace after applying the CRAFT method.

\section{Conclusion}

The research in this paper focuses on the analysis of a logistics chain that takes place in the production process of car seat manufacturing. A Sankey diagram was used to analyse the flows and the current layout. The diagram was made by means of a checkerboard showing the magni- 
Table 4: The costs of material flows after optimization

\begin{tabular}{|c|c|c|c|c|c|}
\hline Receipt - control & 247705.66 & Warehouse - scrap & 258.9 & $2-$ scrap & 126.36 \\
\hline Warehouse - control & 351927.62 & Entry into production - 1 & 7412.69 & $3-4$ & 292.73 \\
\hline Control - entry & 63912.78 & Entry into production - 2 & 5925.71 & $3-5$ & 244 \\
\hline Control - scrap & 677.85 & Entry into production -3 & 10573.97 & 3 - scrap & 341.87 \\
\hline Warehouse -1 & 3141.13 & $\begin{array}{c}\text { Entry into production } \\
\text {-scrap }\end{array}$ & 466.46 & $4-6$ & 2235.8 \\
\hline Warehouse - 2 & 2693.13 & $1-2$ & 355.27 & $4-7$ & 1116.9 \\
\hline Warehouse -3 & 6027.76 & $1-3$ & 378.14 & $5-4$ & 318.9 \\
\hline Warehouse - 5 & 169.76 & 1 - scrap & 258.68 & $6-7$ & 223.78 \\
\hline Warehouse -7 & 192.44 & $2-3$ & 30.1 & 7-finished products & 0 \\
\hline
\end{tabular}

Source: The authors

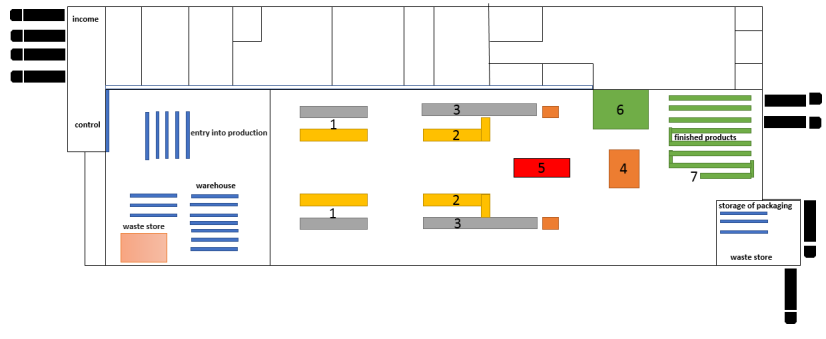

Source: The authors

Figure 5: The new arrangement of the production processes

tudes of material flows. The diagram showed that the material flows often intersect the reverse flows of mixed and recyclable waste.

Subsequently, the CRAFT method, which contributed to the search for an optimized layout of production processes in the company, was used to create the new workplace layout. CRAFT was used on the basis of the costs of handling flows and distances between the individual production processes. As emerged from the analysis, the production process and material flow in the company were very optimized and low-cost. Nevertheless, after application of this method, several new changes in the arrangement were proposed, which, despite a considerable investment, would bring some cost savings.

Although all activities in the logistical processes influence one another and the outcome of the proposed changes cannot be estimated in advance, the current logistical process is of very high quality. It represents an optimal state for the company and brings high productivity of work with excellent economic results. However, through the appropriate application methods, the research has succeeded in finding several possible adjustments that can be applied to reduce costs and optimize the flows of material. These optimizations would reduce costs and improve the production process as well as all manufacturing activities performed by the company employees.

\section{References}

[1] GROS, I. (2016). Velká kniha logistiky. Praha: Vysoká škola chemicko-technologická v Praze. ISBN: 978-80-7080-952-5.

[2] ČUJAN, Z. a MÁLEK, Z. (2008). Výrobní a obchodní logistika. Zlín: Univerzita Tomáše Bati ve Zlíně. ISBN 978-80-7318-730-9.

[3] HITKA, M., LORINCOVÁ, S., PAJTINKOVÁ BARTÁKOVÁ, G., LIŽBETINOVÁ, L., ŠTARCHOŇ, P., LI, CH., ZABOROVA, E., MARKOVA, T., SCHMIDTOVÁ, J., MURA, L. (2018). "Strategic Tool of human resource management for operation of SMEs in the woodprocessing industry," BioResources, vol. 13, no. 2, pp. 2759-2774. DOI: 10.15376/biores.13.2.2759-2774

[4] LIŽBETINOVÁ, L., LORINCOVÁ, S., CAHA, Z. (2016). "The application of the organizational culture assessment instrument (OCAI) to logistics enterprises", Nase more, vol. 63, no. 3, pp. 170-176. DOI: $10.17818 / \mathrm{NM} / 2016 / \mathrm{SI} 17$

[5] JUROVÁ, M. a kolektiv. (2016). Výrobní a logistické procesy $v$ podnikání. Praha : Grada Publishing. ISBN 978-80-247-5717-9.

[6] GIERTL, G.; POTKANY, M.; GEJDOS, M. . (2015). Evaluation of Outsourcing Efficiency Through Costs For Its Use. Conference: 4th World Conference on Business, Economics and Management (WCBEM) Location: Ephesus, TURKEY, Procedia Economics and Finance, Volume: 26 Pages: 1080-1085

[7] STACHOVA, K.; PAPULA, J.; STACHO, Z.; et al. (2019). External Partnerships in Employee Education and Development as the Key to Facing Industry 4.0 Challenges. SUSTAINABILITY Volume: 11 Issue: 2 Article Number: 345

[8] WU, Y., HE, J.-H., (2018) "A remark on Samuelson's variational principle in economics", Applied Mathematics Letters, 84 (2018) 143-147.

[9] KMECOVA, I. (2018). Analysis of the Efficiency of the Educational Processes of the Subjects Business Management, Human Resource Management, and Mathematics, and their Comparison, Conference: 12th International Technology, Education and Development Conference (INTED), Valencia, SPAIN, Pages: 1781-1788

[10] LANGEVILN, A. a RIOPEL, D.. (2005). Logistics systems - Design and Optimizaiton. New York : Springer. ISBN 0-387-24971-0. 
[11] ORAVA, F. (2010). Vývoj a navrhování logistických systémů. Olomouc : Moravská vysoká škola Olomouc. ISBN 978-80-8724039-7.

[12] ŠMÍDA, F. (2007). Zavádění a rozvoj procesního řízení ve firmě. Praha: Grada Publishing. ISBN 978-80-247-169-4

[13] Kucharcikova, A., Miciak, M. (2018). The Application of Human Capital Efficiency Management towards the Increase of Performance and Competitiveness in an Enterprise Operating in the Field of Distribution Logistics. NASE MORE Volume: 65 Issue: 4 Pages: 276-283

[14] WEGNER, U. a WEGNER, K. (2017). Einführung in das LogistikManagement: Prozesse - Strukturen - Anwendungen. Wiesbaden : Springer Verlag. 978-3-658-13674-1.

[15] NĚMEC, F., HITKA, M., LORINCOVÁ, S., TURÍNSKÁ, L. (2015). “The storage area market in the particular territory", Nase more, vol. 62, pp. 131-138. DOI 10.17818/NM/2015/SI3

[16] KLARIC, K., GREGER, K., KLARIC, M., ANDRIC, T., HITKA, M., KROPIVSEK, J., (2016). "An exploratory assessment of FSC chain of custody certification benefits in Croatian wood industry “, Drvna Industrija, vol. 67, no. 3, pp 241-248 DOI: 10.5552/drind.2016.1540

[17] ŘEPA, V. (2007). Podnikové procesy, procesní řizení a modelování. Praha : Grada Publishing, 2007. ISBN 978-80-247-2252-8.

[18] HIREGOUDAR, Ch. a REDDY, B. Raghavendra. (2007). Facility Planning \& Layout Design. Shaniwar Peth : Technical Publications Pune, 2007. ISBN 81-8431-291-1.

[19] GARCIA-GARCIA, G., Stone, J. \& Rahimifard, S. (2019). "Opportunities for waste valorisation in the food industry - A case study with four UK food manufacturers", Journal of Cleaner Production, vol. 211, pp. 1339-1356.

[20] GONZALEZ HERNANDEZ, A., LUPTON, R.C., WILLIAMS, C. \& Cullen, J.M. (2018). "Control data, Sankey diagrams, and exergy: Assessing the resource efficiency of industrial plants", Applied Energy, vol. 218, pp. 232-245.
[21] GONZALEZ HERNANDEZ, A., PAOLI, L. \& CULLEN, J.M. (2018). "How resource-efficient is the global steel industry?", Resources, Conservation and Recycling, vol. 133, pp. 132-145.

[22] ALTINKILINC, M. (2004), "Simulation-based layout planning of a production plant", Proceedings - Winter Simulation Conference, pp. 1079

[23] ATIEH, A.M., KAYLANI, H., ALMUHTADY, A. \& Al-Tamimi, O. (2016). "A value stream mapping and simulation hybrid approach: application to glass industry", International Journal of Advanced Manufacturing Technology, vol. 84, no. 5-8, pp. 1573-1586.

[24] CHOVANCOVÁ, M., STOPKA, O., KLAPITA, V. (2017). “Modeling the distribution network applying the principles of linear programming". 21st International Scientific on Conference Transport Means 2017, Juodkrante; Lithuania; 20-22 September 2017, Code 135093, 2017, pp. 73-77. ISSN 1822-296X.

[25] BARTUSKA, L., STOPKA, O., CHOVANCOVA, M., LIZBETIN, J.(2016). "Proposal of Optimizing the Transportation Flows of Consignments in the Distribution Center". Transport Means - 20th International Scientific Conference on Transport Means (Juodkrante, LITHUANIA), pp. 107-111, 2016. ISSN 1822-296X.

[26] CAMBRON, K.E. \& EVANS, G.W. (1991). "Layout design using the analytic hierarchy process", Computers and Industrial Engineering, vol. 20, no. 2, pp. 211-229.

[27] HARI PRASAD, N., RAJYALAKSHMI, G. \& SREENIVASULU REDDY, A. (2014). "A typical manufacturing plant layout design using CRAFT algorithm", Procedia Engineering, pp. 1808.

[28] NÝVLT, V. (2016). "Life cycle costing in BIM management". CESB 2016 - Central Europe Towards Sustainable Building 2016: Innovations for Sustainable Future. pp. 1438-1444

[29] ZARATE, D.C., BODIC, P.L., DWYER, T., GANGE, G. \& STUCKEY, P. (2018), "Optimal Sankey Diagrams Via Integer Programming", IEEE Pacific Visualization Symposium, pp. 135. 